\title{
Implementasi Wireless Quality of Service dengan Metode Load Switching Jaringan Seluler Menggunakan Software Defined Network untuk Meningkatkan Network Reliability pada Jaringan Dinamis
}

\author{
Yoga Bayu Aji Pranawa, Royyana Muslim Ijtihadie, dan Waskitho Wibisono \\ Jurusan Teknik Informatika, Fakultas Teknologi Informasi, Institut Teknologi Sepuluh Nopember (ITS) \\ Jl. Arief Rahman Hakim, Surabaya 60111 Indonesia \\ e-mail: roy@if.its.ac.id, waswib@if.its.ac.id
}

\begin{abstract}
Abstrak-Wireless Quality of Service (QOS) adalah salah satu dimensi mobilitas, yaitu sebuah metode yang digunakan untuk menjaga kualitas suatu jaringan nirkabel. QOS diperlukan sebagai sebuah metode untuk memenuhi kriteria pelayanan sistem bagi pengguna, yaitu confidentiality, integrity, dan availability. Beberapa aspek yang menjadi topik utama dalam QOS adalah failure and recovery mechanism, variable bandwidth, computing distribution, discovery mechanism, variable lantency, dan performance feedback. Wireless yang dibahas pada penelitian ini dititik beratkan pada jaringan seluler yang cenderung tidak reliable pada daerah tertentu. Oleh karena itu dibutuhkan sebuah mekanisme yang dapat mengatasi tidak stabilnya jaringan seluler tersebut. mplementasi mekanisme yang diterapkan pada penelitian ini adalah dengan menerapkan load switching pada jaringan seluler dengan menggunakan beberapa provider dan menerapkan teknologi Software Defined Network (SDN). Berdasarkan hasi uji coba dapat disimpulkan bahwa sistem yang dibuat pada penelitian ini dapat menerapkan wireless quality of service dan meningkatkan network reliability sebesar $65,29 \%$ dan $83,87 \%$ lebih baik untuk penggunaan tanpa waktu tunggu dan dengan waktu tunggu pada suatu jaringan dinamis.
\end{abstract}

Kata Kunci-wireless quality of service, software defined network, load switching, jaringan seluler, OpenFlow.

\section{PENDAHULUAN}

$\mathrm{P}$ ERKEMBANGAN teknologi informasi (khususnya internet) yang sangat pesat dapat merubah pola hidup manusia dalam menjalani aktivitas sehari-hari. Internet dibutuhkan karena hampir semua aktivitas manusia pada era modern ini menuntut mobilisasi koneksi yang tinggi. Selain dituntut untuk mobilisasi koneksi yang tinggi, manusia pada era modern ini juga dituntut untuk multitasking, artinya dapat melakukan beberapa tugas atau aktivitas dalam waktu yang bersamaan. Oleh karena itu, dibutuhkan koneksi internet yang memadai untuk memenuhi kebutuhan mobilisasi dan multitasking yang dapat dinikmati kapanpun dan dimanapun meski sedang dalam perjalanan.

Salah satu infrastruktur yang digunakan agar dapat menikmati internet adalah melalui jaringan seluler (Cellular
Network). Jaringan seluler menggunakan Base Transceiver Station (BTS) sebagai titik akses. Teknologi pada jaringan seluler yang berkembang saat ini adalah teknologi 4G (Fourth Generation). Teknologi 4G menggunakan Long-Range Base Technologies yang memungkinkan pengguna untuk melakukan akses kepada layanan yang berbeda. Layanan 4G akan memberikan akses data melalui beberapa teknologi berbasis IP dan menawarkan beberapa bit rates sampai dengan 50 Mbps [1]. Meskipun teknologi jaringan seluler yang sudah dikembangkan saat ini sudah mendukung kecepatan akses yang tinggi dan jangkauan yang lebih luas, perangkat komunikasi yang menggunakan jaringan seluler harus berada pada range BTS agar dapat berkomunikasi satu sama lain. Apabila sebuah perangkat seluler terlalu jauh dari tower BTS maka perangkat tersebut tidak dapat melakukan komunikasi secara maksimal.

Ketika sedang melakukan suatu perjalanan khususnya perjalanan darat (kereta api, bus, maupun kendaraan pribadi) seringkali terdapat suatu wilayah yang tidak dapat dijangkau oleh jaringan seluler. Hal ini menyebabkan pengguna tidak dapat mengakses suatu informasi melalui jaringan dan tidak memenuhi persyaratan Quality of Service (QOS). Agar memenuhi persyaratan Quality of Service, salah satu poin yang harus dipenuhi adalah suatu arsitektur jaringan tersebut dapat menangani bandwidth yang berubah-ubah (variable bandwidth) setiap saat [1]. Salah satu metode yang dapat digunakan untuk menangani hal ini adalah dengan melakukan load switching untuk pemilihan bandwidth tertinggi pada beberapa ISP menggunakan Software Defined Network (SDN) yang di implementasikan pada teknologi WLAN. Load switching yang dimaksud adalah pemilihan jalur aliran data dipilih berdasarkan kondisi resource yang terbaik dengan menggunakan parameter tertentu.

Software Defined Network (SDN) dipilih sebagai implementasi sistem karena SDN menyediakan fasilitas Application Programming Interface (API). API yang tersedia pada SDN dapat mengetahui statistik suatu perangkat dan memberikan kebebasan programmer untuk mengembangkan 
sebuah aplikasi pada perangkat tersebut. Infrastruktur SDN juga memungkinkan sebuah arsitektur jaringan tidak terpaku pada perangkat dengan vendor tertentu, karena SDN menggunakan standar protokol OpenFlow untuk berkomunikasi dengan sebuah perangkat.

Makalah ini membahas tentang penerapan load switching jaringan seluler dengan menggunakan software defined network yang ditujukan untuk meningkatkan network reliability pada jaringan dinamis dan menerapkan aspek wireless quality of service. Struktur penulisan makalah ini diisusun sebagai berikut: bagian 2 membahas tentang tinjauan pustaka. Bagian 3 membahas tentang analisis dan perancangan arsitektur sistem yang digunakan pada makalah ini. Bagian 4 berisi implementasi sistem yang telah dirancang pada lingkungan pengembangan. Bagian 5 adalah uji coba yang telah dilakukan dengan melakukan perhitungan delay time dan reliability. Bagian 6 merupakan kesimpulan dari keseluruhan sistem yang telah dibuat.

\section{TINJAUAN PUSTAKA}

\section{A. Wireless Quality of Service}

Quality of Service (QOS) dalam konteks jaringan nirkabel (wireless) adalah salah satu dimensi mobilitas, yaitu suatu hal yang dapat membedakan aplikasi mobile berbeda dengan kondisinya ketika diam [1]. QOS diperlukan sebagai sebuah metode untuk memenuhi kriteria pelayanan sistem bagi pengguna, yaitu confidentiality, integrity, dan availability. Beberapa aspek yang menjadi topik utama dalam QOS adalah failure and recovery mechanism, variable bandwidth, computing distribution, discovery mechanism, variable lantency, dan performance feedback. Solusi yang diberikan berdasarkan problem dari beberapa aspek tersebut berbeda-beda tergantung dari arsitektur yang kita tentukan untuk mengimplementasikan sistem yang kita buat.

\section{B. Load Switching}

Load Switching adalah sebuah metode yang termasuk dalam metode load balancing yang berfungsi untuk mendistribusikan lalu lintas data diantara beberapa sumber daya server [2]. Sebuah perangkat atau aplikasi yang memiliki fungsi untuk menjalankan metode load balancing disebut dengan load balancer. Load balancer bertindak sebagai pengatur lalu lintas yang menerima permintaan lalu lintas yang datang. Kemudian load balancer meneruskannya kepada semua server yang mampu menangani permintaan tersebut dengan cara memaksimalkan kecepatan dan kapasitas dari pendayagunaan server dan memastikan bahwa tidak ada satupun server yang bekerja terlalu banyak (overworked) sehingga menyebabkan performa server menurun. Implementasi load balancer memiliki fungsi yang beragam, diantaranya adalah sebagai load switching, traffic engineering, dan intelligent traffic switching.

Algoritma yang digunakan pada metode load balancing sangat bervariasi, tergantung dengan kebutuhan sistem dan permasalahan yang akan ditangani. Algoritma load balancing yang sering digunakan pada makalah ini adalah penerapan dari algoritma least connection. Algoritma least connection yaitu sebuah metode pendistribusian lalu lintas data yang masuk dengan cara mengirimkan permintaan yang baru kepada server dengan koneksi aktif ke klien yang paling sedikit [4]. Namun pada makalan ini akan dimodifikasi dengan menggunakan koneksi aktif ke server yang paling tinggi. Sehingga koneksi yang didapatkan oleh client lebih stabil.

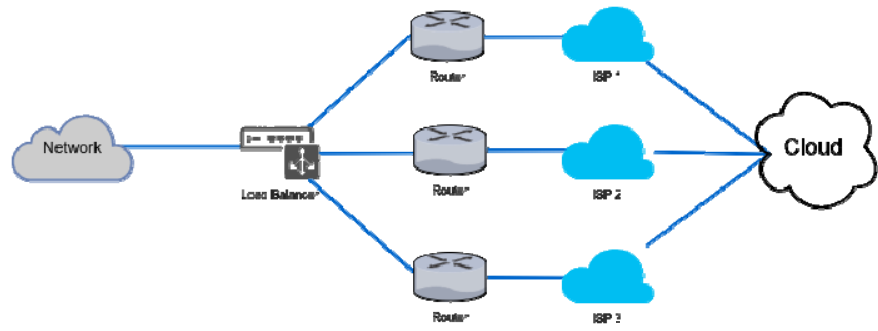

Gambar 1. Algoritma internet service provider load switching

\section{Jaringan Seluler}

Jaringan seluler (Cellular Network) adalah sebuah jaringan telekomunikasi yang menggunakan jaringan radio dan menggunakan beberapa pemancar yang berdaya rendah (multiple low-power transmitter) kurang dari $100 \mathrm{~W}$ [6]. Karena sistem pemancar yang digunakan memiliki daya yang rendah, maka jaringan seluler dibagi menjadi beberapa area. Setiap area pada jaringan seluler dibagi menjadi beberapa sel (cell), setiap sel akan dilayani oleh sebuah antena dan akan dialokasikan pada frekuensi tertentu yang dilayani oleh base station. Sebuah base station terdiri dari transmitter, receiver, dan control unit.

Setiap base station yang berdekatan dapat berkomunikasi dan akan membentuk sebuah pattern yang menyelimuti area tersebut. Pattern yang digunakan biasanya membentuk square pattern atau hexagonal pattern.

\section{Software Defined Network}

Software Defined Network (SDN) merupakan sebuah arsitektur jaringan yang dinamis, dapat dikelola (manageable), hemat biaya, dan mudah beradaptasi dengan perubahan kondisi jaringan [7]. Beberapa komponen penting dalam Software Defined Network yang penting adalah controller dan protokol OpenFlow. Controller merupakan sebuah aplikasi yang menjadi titik strategis dalam Software Defined Network. Controller mengelola aliran kontrol pada switch/router melalui southbound APIs dan mengelola aplikasi beserta proses bisnis melalui northbound APIs untuk mengimplementasikan jaringan cerdas [9]. OpenDaylight Controller adalah salah satu controller Java Virtual Machine (JVM) software yang dapat berjalan di semua sistem operasi dan hardware selama mendukung Java [10]. OpenFlow adalah sebuah standar komunikasi pada jaringan yang mendefinisikan antara lapisan kontrol dan lapisan forwarding dari sebuah arsitektur SDN. OpenFlow memungkinkan akses langsung dan melakukan manipulasi dari forwarding plane pada sebuah perangkat jaringan seperti switch dan router, baik secara fisik maupun virtual (hypervisor-based) [11]. 


\section{E. Dynamic Network Area}

Dynamic network adalah suatu kondisi dimana jaringan yang diterima pada sebuah perangkat mengalami perubahan kenaikan atau penurunan secara signifikan ketika berada di suatu wilayah tertentu. Dynamic network biasanya ditemui ketika sebuah perangkat berpindah dari satu tempat ke tempat lainnya.

Salah satu area yang termasuk area paling buruk pada jaringan dinamis adalah blank spot area. Blank spot area atau dalam referensi lain disebut sebagai dead zone, call drop, dan lain-lain adalah sebuah area dimana jaringan seluler tidak dapat digunakan karena mengalami interferensi atau kondisi sinyal yang rendah (karena terlalu jauh dengan tower BTS) [6]. Akibat dari blank spot area ini adalah paket yang dikirimkan oleh client akan di drop oleh sistem, sehingga komunikasi dan pertukaran data tidak dapat dilakukan.

\section{ANALISIS DAN PERANCANGAN SISTEM}

\section{A. Deskripsi Umum Sistem}

Sistem yang dibangun pada makalah ini berupa sebuah aplikasi load switching yang diimplementasikan pada software defined network (SDN) dengan controller OpenDaylight. Aplikasi load switching yang dibuat diharapkan dapat beradaptasi dengan kondisi jaringan yang tidak stabil, khususnya jaringan seluler. Sehingga aplikasi dapat menyesuaikan dan meminimalisasi adanya gangguan ketika kondisi jaringan sedang tidak stabil.

Secara umum, aplikasi akan menggunakan 4 (empat) modem sebagai jalur koneksi. Berdasarkan 4 (empat) perangkat modem tersebut akan diambil koneksi terbaik berdasarkan kualitas throughput yang dihasilkan oleh masing-masing koneksi per detik. Masing-masing data throughput tersebut kemudian dikirimkan ke controller oleh host router untuk memodifikasi tabel throughput port (tx dan rx) pada tabel port controller. Setelah data throughput pada tabel throughput port pada controller dimodifikasi, maka aplikasi yang berada pada mesin controller akan memasukkan data tersebut kedalam database agar data tersimpan dan dapat dianalisis lebih lanjut.

Setelah data throughput dimasukkan kedalam database maka aplikasi akan menentukan jalur terbaik saat itu. Berikut ini merupakan rumus parameter yang dikirim oleh host router:

$$
\text { Parameter }=\frac{R x_{b p s}+T x_{b p s}}{R T T}
$$

Keterangan:

$\mathrm{Rx}_{\mathrm{bps}}=$ Throughput paket yang diterima per detik (bytes)

$\mathrm{Tx}_{\mathrm{bps}}=$ Throughput paket yang dikirim per detik (bytes)

RTT = Round Trip Time (waktu yang dibutuhkan sebuah paket untuk kembali ke pengirim) (miliseconds)

kemudian aplikasi akan melakukan pembuatan flow (jalur data) yang akan digunakan oleh client ke internet. Proses tersebut akan berlangsung terus menerus selama aplikasi dijalankan.

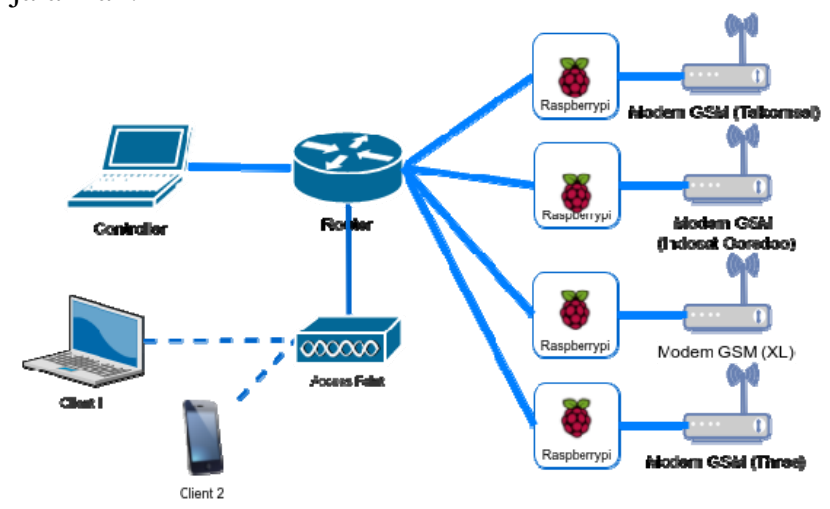

Gambar 2. Arsitektur sistem secara umum

Arsitektur sistem secara umum ditunjukkan pada gambar 2. Pada gambar 2 diatas dapat dilihat bahwa mesin controller akan menjalankan 2 (dua) aplikasi yaitu controller OpenDaylight dan aplikasi load switching. Router akan menjalankan protokol OpenFlow. Sedangkan host router akan menjalankan aplikasi throughput monitor dan melakukan pengiriman parameter throughput.

\section{B. Arsitektur Sistem}

Rancangan arsitektur sistem pada makalah ini dibuat dengan menggunakan protokol OpenFlow untuk berkomunikasi dengan controller. Protokol OpenFlow dirancang dengan memisahkan antara lapisan aplikasi (application layer), lapisan kontrol (control layer), dan lapisan infrastruktur (infrastructure layer). Arsitektur sistem OpenFlow yang dipakai menggunakan jalur Secure Socket Layer (SSL) untuk menghubungkan antara controller dengan OpenFlow Enabled Switch. Arsitektur yang digunakan ditunjukkan pada gambar 3 dibawah.

Alur dari proses sebuah pertukaran data dimulai dari masuknya suatu paket ke dalam OpenFlow switch. OpenFlow switch akan mengirimkan data paket tersebut kepada controller untuk melakukan pengecekan pada flow table terhadap sebuah paket, apakah sudah terdapat data paket yang match dengan paket yang baru masuk. Kemudian controller akan memberikan respon terhadap paket yang masuk untuk membuat suatu perlakuan terhadap paket tersebut, apakah di-drop atau dibuatkan sebuah flow table baru berdasarkan paket yang masuk tersebut. Secara garis besar, alur dari proses penanganan sebuah paket digambarkan pada gambar 4 dibawah. 


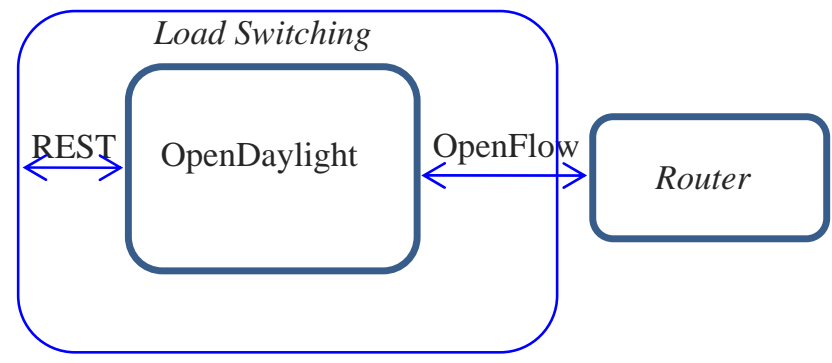

Gambar 3. Arsitektur sistem dengan software defined netowk

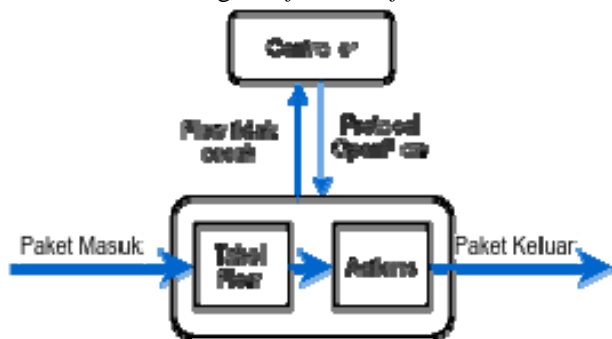

Gambar 4. Proses penanganan sebuah paket pada OpenFlow

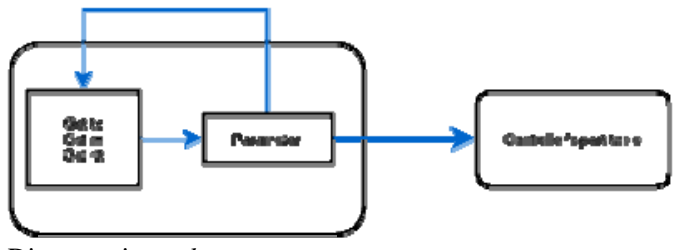

Gambar 5. Diagram sistem host router

Aplikasi yang berjalan pada host router secara periodik akan melakukan kalkulasi throughput dan mengirimkannya ke host router yang lain untuk melakukan modifikasi data throughput port pada lapisan kontrol. Sistem yang berjalan pada host router digambarkan pada gambar 5 diatas.

\section{IMPLEMENTASI}

\section{A. Implementasi Rute}

Implementasi rute memiliki tujuan untuk menentukan daerah yang memiliki kualitas jaringan yang kurang stabil. Rute dipilih berdasarkan analisis coverage, analisis download, dan analisis upload pada suatu wilayah. Aplikasi yang digunakan sebagai acuan analisis adalah www.sensorly.com yang menyediakan data statistik jaringan seluer. Berdasarkan data didapat pada sensorly.com, maka ditentukan rute sebagai berikut:

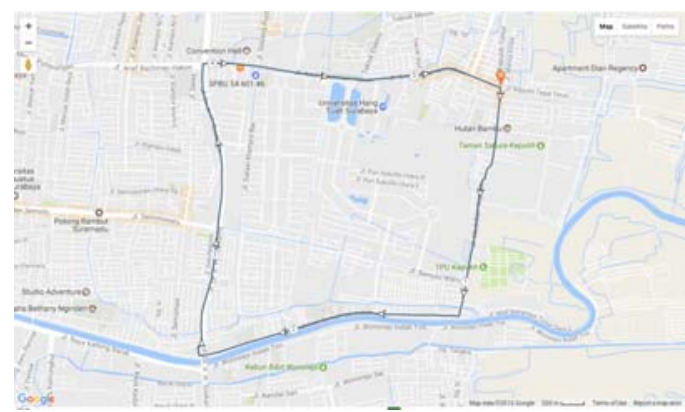

Gambar 6. Implementasi rute yang ditempuh untuk uji coba (diambil dari www.plotaroute.com)

\section{B. Implementasi Antarmuka}

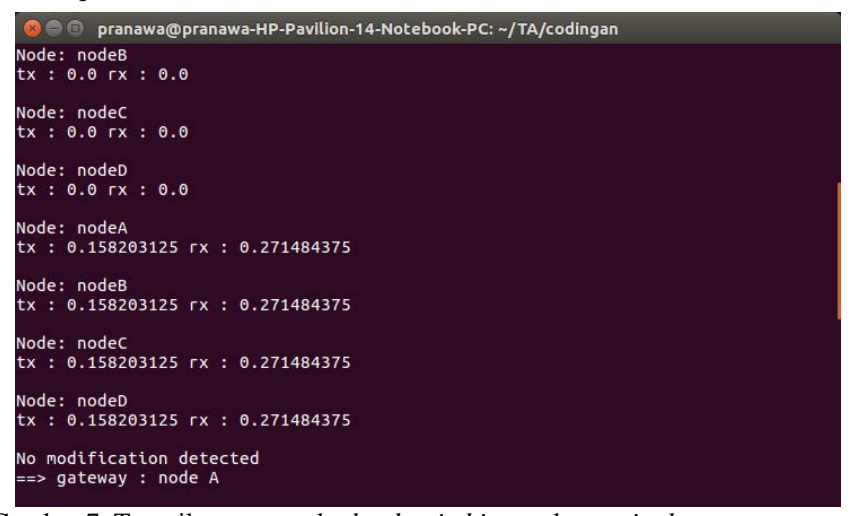

Gambar 7. Tampilan antarmuka load switching pada terminal

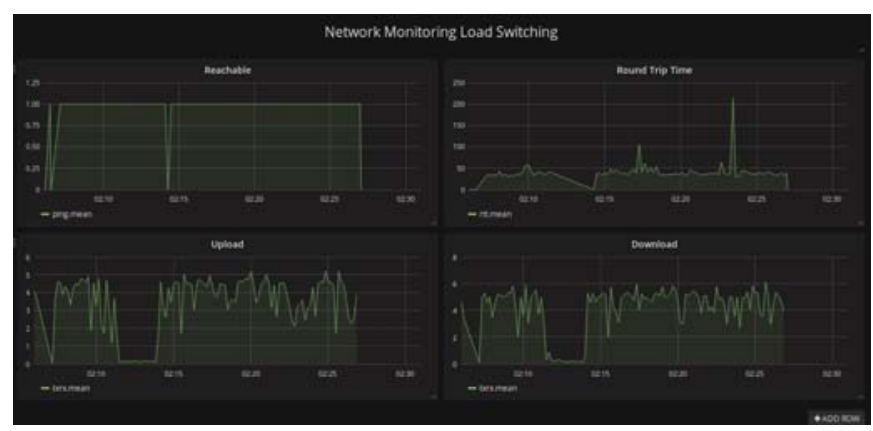

Gambar 8. Tampilan antarmuka network monitoring pada browser

Implementasi antarmuka pada makalah ini menggunakan antarmuka command line pada terminal untuk antarmuka load switching, dan menggunakan antarmuka web untuk menampilkan grafik network monitoring. Tampilan antarmuka pada makalah ini ditunjukkan pada gambar 7 dan gambar 8 diatas.

\section{UJI COBA DAN EVALUASI}

Pengujian performa pada sistem ini dilakukan untuk mengetahui seberapa baik kualitas throughput yang didapat oleh pengguna sebelum dan sesudah menggunakan mekanisme load switching menggunakan software defined network dengan controller OpenDaylight. Uji coba performa yang dilakukan meliputi pengukuran network reachable, pengukuran round trip time, pengukuran pengunduhan berkas, dan pengukuran unggah berkas. Pada uji coba performa yang dilakukan akan dihitung jumlah delay time yaitu total setiap delay time yang dibutuhan oleh sistem untuk menaikkan kualitas jaringan ketika terjadi penurunan kualitas jaringan secara signifikan. Perhitungan delay time dan presentase reliability ditunjukkan pada persamaan berikut ini.

Selisih delay time tanpa waktu tunggu $=1224,5-425=799,5$ detik

reliability tanpa waktu tunggu $=\frac{799,5}{1224,5} \times 100=65,29 \%$

Selisih delay time dengan waktu tunggu $=1224,5-197,5=$ 1027 detik

reliability dengan waktu tunggu $=\frac{1027}{1224,5} \times 100=83,87 \%$

Berdasarkan hasil uji performa didapatkan data sebagai 
berikut:

Tabel 1.

Tabel rata-rata jumlah delay time pada uji performa tanpa load switching

\begin{tabular}{lr}
\hline \hline \multicolumn{1}{c}{ Uji Performa tanpa Load Switching } & $\begin{array}{c}\text { Jumlah Delay Time } \\
\text { (detik) }\end{array}$ \\
\hline Uji performa network reachable & 1106 \\
Uji performa round trip time & 1232 \\
Uji performa pengunduhan & 1280 \\
Uji performa pengunggahan & 1280 \\
Rata-rata & 1224,5 \\
\hline \hline
\end{tabular}

Tabel 2.

Tabel rata-rata jumlah delay time pada uji performa menggunakan load switching tanpa waktu tunggu

\begin{tabular}{lc}
\hline \hline $\begin{array}{c}\text { Uji Performa menggunakan Load Switching } \\
\text { tanpa Waktu Tunggu }\end{array}$ & $\begin{array}{c}\text { Jumlah Delay Time } \\
\text { (detik) }\end{array}$ \\
\hline Uji performa network reachable & 170 \\
Uji performa round trip time & 380 \\
Uji performa pengunduhan & 540 \\
Uji performa pengunggahan & 610 \\
Rata-rata & 425 \\
\hline \hline
\end{tabular}

Tabel 3.

Tabel rata-rata delay time pada uji performa menggunakan load switching dengan waktu tunggu

\begin{tabular}{lr}
\hline \hline \multicolumn{1}{c}{$\begin{array}{c}\text { Uji Performa menggunakan Load Switching } \\
\text { dengan Waktu Tunggu }\end{array}$} & $\begin{array}{c}\text { Jumlah Delay Time } \\
\text { (detik) }\end{array}$ \\
\hline Uji performa network reachable & 60 \\
Uji performa round trip time & 200 \\
Uji performa pengunduhan & 240 \\
Uji performa pengunggahan & 290 \\
Rata-rata & 197,5 \\
\hline \hline
\end{tabular}

Tabel 4.

Tabel perbandingan rata-rata jumlah delay time

\begin{tabular}{lr}
\hline \hline \multicolumn{1}{c}{ Uji Performa } & $\begin{array}{c}\text { Jumlah Rata-rata } \\
\text { Delay Time (detik) }\end{array}$ \\
\hline $\begin{array}{l}\text { Uji performa tanpa load switching } \\
\text { Uji performa menggunakan load switching tanpa }\end{array}$ & 1224,5 \\
waktu tunggu & 425 \\
$\begin{array}{l}\text { Uji performa menggunakan load switching dengan } \\
\text { waktu tunggu }\end{array}$ & 197,5 \\
\hline \hline
\end{tabular}

\section{KESIMPULAN}

Implementasi load switching jaringan seluler menggunakan software defined network yang dilakukan telah berhasil diterapkan dengan baik. Implementasi load switching yang dibuat telah menerapkan aspek wireless quality of service dengan dibuktikan dengan penurunan delay time dan peningkatan network reliability.

Kualitas jaringan yang didapatkan menggunakan sistem load switching menggunakan software defined network memiliki pengurangan jumlah delay time rata-rata 799,5 detik apabila tanpa menggunakan waktu tunggu dan 1027 detik apabila menggunakan waktu tunggu. Sistem yang dibuat memiliki tingkat reliability sebesar 65,29\% apabila tanpa menggunakan waktu tunggu dan 83,87\% apabila menggunakan waktu tunggu.

\section{DAFTAR PUSTAKA}

[1] R. B'Far, “Mobile Computing Principles", Cambridge: Cambridge University Press, 2005.
[2] Kopparapu, Chandra, load switching Servers, Firewalls, and Caches, New York: New York, 2002.

[3] C. Ellrod, "Load Balancing - Round Robin,” Citrix, 3 September 2010. [Online].Available:https://www.citrix.com/blogs/2010/09/03/load-balan cing-round-robin/. [Diakses 6 Januari 2017].

[4] C. Ellrod, "Load Balancing - Least Connections," Citrix, 2 September 2010.[Online].Available:https://www.citrix.com/blogs/2010/09/02/loadbalancing-least-connections/. [Diakses 6 Januari 2017].

[5] C. Ellrod, "Load Balancing - Hash Method," Citrix, 4 September 2010. [Online].Available:https://www.citrix.com/blogs/2010/09/04/load-balan cing-hash-method/. [Diakses 6 Januari 2017].

[6] W. Stallings, "Wireless Connections and Networking Second Edition", New Jersey: Pearson Education, 2005.

[7] "Software-Defined Networking (SDN) Definition", Open Networking Foundation.[online].Available:https://www.opennetworking.org/sdn-res ources/sdn-definition. [diakses 6 Januari 2017].

[8] "Wireless Local Area Network (WLAN)", Techopedia. [Online].Available:https://www.techopedia.com/definition/5107/wireles s-local-area-network-wlan. [diakses 6 Januari 2017].

[9] “What are SDN Controllers (or SDN Controllers Platforms)?”, SDX Central.[Online].Available:https://www.sdxcentral.com/sdn/definitions/s dn-controllers/ [diakses 6 Januari 2017].

[10] "OpenDaylight User Guide", Linux Foundation. [Online]. Available:https://www.opendaylight.org/sites/opendaylight/files/bk-user -guide.pdf. [diakses 6 Januari 2017].

[11] "OpenFlow", Open Networking Foundation. [Online]. Available: https://www.opennetworking.org/sdn-resources/openflow. [diakses 6 Januari 2017] 